FTAMP 17.71 .07

\author{
Мәмбетов Ж.О.', Кенжеқожаева А.ㄹ, \\ Сүлеймен Демирел атындағы Университеттің \\ ${ }^{1}$ доценті, ф. ғ. к., ${ }^{2} 2$ курс магистранты, Қазақстан, Қаскелен қ., \\ e-mail: zholdas_19@mail.ru,ak_bota555@mail.ru

\section{ҚАЗАК ӘАЕБИЕТІНАЕГІ ТАРИХИ ШЫҒАРМАААР ЖӘНЕ ОҚЫТУ ӘАІСТЕМЕСІ}

\begin{abstract}
Бұл мақалада қазақ әдебиетіндегі тарихи шығармалардың, ондағы тарихи кейіпкерлердің, сондай-ақ көркем шығармаларда кездесетін тарихи оқиғалардың қоғамдағы маңызы, қазіргі кезеңдегі орны туралы айтылған. Қазақ жазушылары шығармаларына тарихи қолтаңба, тарихи форма бере отырып, қазақ халқының дәстүрлері мен тарихи санасының жоғалмауын көздегені анық. Шығармалардағы тарихи кейіпкерлері арқылы, олардың сипаттамасы, іс-әрекеттері арқылы оқырмандарға жақсы мен жаманның арасын жіктеп, өз дәуірлерінің батырларын, олардың ерліктерін сипаттай келе жас ұрпақты елдікке, ерлікке баули түседі. Мақалада көптеген шығармалар қамтылып, кейбіріне шағын тақырыптық талдау жасалған. Нақтырақ айтсақ, мақалада 20 және 21 ғасырларда жарыққа шыққан қазақ, жазушыларының тарихи романдары қамтылып, жаңа заман әдебиетіндегі өзгерістер мен жаңа бағыттар жайлы сөз қозғалған.

Түйін сөздер: тарихи шығарма, тарихи проза, танымдық қызмет, оқыту әдістемесі, әдістемелік мәселелер.
\end{abstract}

\author{
Mambetov Zh.O. ${ }^{1}$, Kenzhekozhayeva A. ${ }^{2}$, \\ ${ }^{1}$ Candidate of Philological Sciences, docent, ${ }^{2}$ Master's student of 2 nd year \\ of Suleyman Demirel University, Kazakhstan, Kaskelen, \\ e-mail: zholdas_19@mail.ru, ak_bota555@mail.ru
}

\title{
Historical works in the Kazakh literature and methods of teaching
}

This article describes the importance of Kazakh literature, its historical heroes, and also historical events in society and their role in modern times. Kazakh writers were interested in preserving the traditions and historical consciousness of the Kazakh people by giving them a historical signature and historical form. Readers are taught to differ good and bad by historical heroes in their works, their characteristics, description of their heroic deeds, they awaken heroism and peacefulness in the hearts of young generation through characteristics and actions of heroes. The article includes a large number of works, some of which were thematically analyzed. In particular, the article covers the historical novels of Kazakh writers, published in the 20th and 21 st centuries, as well as changes and innovations in modern literature.

Key words: historical work, historical prose, cognitive activity, teaching methods, methodological problems.

\author{
Мамбетов Ж.О. ${ }^{1}$, Кенжекожаева А. ${ }^{2}$, \\ ${ }^{1}$ к. ф.. н., Аоцент, ${ }^{2}$ магистрант 2 курса \\ Университета имени Сулеймана Аемиреля, Казахстан, г. Каскелен, \\ e-mail: zholdas_19@mail.ru, ak_bota555@mail.ru \\ Исторические произведения \\ в казахской митературе и методика их преподавания
}

В Аанной статье рассказывается о важности произведений казахской митературы, исторических героях, встречающихся в них, а также описанных в них исторических событий в обществе и роли в современности. Придавая им историческую подпись, историческую 
форму, казахские писатели были заинтересованы в сохранении традиций и исторического сознания казахского народа. С помощью исторических героев в своих работах, характеристике персонажей, описанию их героических поступков учат читателей разделять добро и зло, через их характеристики и поступки, они пробуждают в молодом поколении героизм и миролюбие. Статья рассматривает большое количество работ, был проведен их тематический анализ. В частности, статья освещает исторические романы казахских писателей, опубликованные в 20-м и 21-м веках, а также изменения и нововведения в современной митературе.

Кмючевые слова: историческое произведение, историческая проза, познавательная деятельность, методика обучения, методологические проблемы.

\section{Kipicпе}

Қазақ әдебиеті негізінен фольклорлық шығармалар мен эпостық жырлардан бастау алады. Сондықтан болар заманауи әдебиеттің өзінде тарихи бейнелер, оқиғалар жиі кездесетіні рас. Оның үстіне біздің ұлт тарихи жадыны өшіруге тырысқан Ресей империясы, КСРО секілді алып империялардың құрамында болып, қаншама жыл езгі көрді, өз елінде бөтеннің күйін кешті. Тіпті өз тілімізді ұмытуға шақ қалған кезеңдерді, өте ауыр уақыттарды бастан өткердік. Қазақ әдебиеті осындай аумалы-төкпелі замандарда қазақ тарихының ұмытылмауына үлкен себепші болды. Тарихи жадыны қалпына келтіруде зор рөл атқарды. КСРО-дағы цензура кезінде де жазушыларымыз қолынан келгенінше, бірі куғын-сүргін көріп, бірі империяның саясатына бейімдеп те жазып жүрді. Қазақтың кез келген классикалық шығармасын алатын болсақ, барлығында тарихи фактілер мен дәйектер, сол кезеңдердің кейіпкерлері жүреді. Кей шығармаларда басқа есімдермен жүргенімен, басым көпшілігі тарихтан алынған.

Өткен ғасырдағы Мұхтар Әуезовтің «Абай жолы», Жүсіпбек Аймауытовтың «Қартқожа», Ғабит Мүсіреповтің «Оянған өлке», Сәбит Мұқановтың «Ботагөз», Ғабиден Мұстафиннің «Қарағанды», Әбдіжаміл Нұрпейісовтің «Қан мен тер», Ғабит Мүсіреповтің «Ұлпан» романдары әдебиетіміздің асыл жауһарлары ретінде ұлттық санамыздан өз орнын алып, әдебиет тарихына берік орнықты. Ілияс Есенберлиннің «Көшпенділер», «Алтын Орда» секілді романдарының орны мүлдем бөлек. Себебі осы шығармалар жазушының қиялынан бөлек, толықтай тарихи деректерге құрылған.

Сонымен қатар қазақ әдебиетінде, әсіресе КСРО кезеңінде белгілі бір тарихи кезеңдерге, науқандарға, жетістіктерге байланысты шығармалар туды. Мысалы тың игеру, қазақ жерінен мұнайдың табылуы, кен орындарының ашылуы секілді тарихи оқиғалар көптеген әдеби шығармаларға арқау болды. Ондағы көптеген кейіпкерлердің шынайы өмірде болғаны дәлелдеуді қажет етпейді.

Ал ұлы Абай дәстүрінен бастау алған ойлы әдебиетіміздегі роман жанрына туындаған шығармаларымыздың кейінгі даму көкжиегі қай жағалауларға бастайды?

\section{Негізгі бөлім}

Тарихи романдар - белгілі бір тарихи оқиғаға байланысты туған шығарма. Тарихи шығармаларда оқиғаның дәлдігі сақтала бермейді, әр кезеңнің тарихи-әлеуметтік, қоғамдықсаяси бет-бедері көркемдік тұрғыдан қорытылып бейнеленеді. Бұл жанрда жалпыхалықтық мемлекеттік мүдделер басты сипат алады. Тарихи роман негізін тарихта болған оқиға желісі құрайды. Тарихи роман кейіпкерлері де - өмірде болған адамдар $[1,238]$. Тарихи оқиғалар мен тарихи тұлғалар өмірін, сол дәуірді суреттейтін шығармалар қатарына И. Жақановтың «Ықылас» (1990), Ж. Ахмадидің «Дүрбелең» (1990), «Шырғалаң» (1997), «Есенгелді би» (2004), Қ. Жұмаділовтің «Дарабоз» (1994), Д. Досжанның «Алыптың азабы» (1997), Ұ. Доспамбетовтың «Қызыл жолбарыс» (2000), «Абылайдың ақ туы» (2004), Х. Әдібаевтың «Отырар ойраны» (2001), К. Сегізбайдың «Беласқан» (2001), Т. Зәкенұлының «Көк бөрілердің көз жасы» (2003), С. Сматаевтың «Елім-ай» (2003), Р. Тоқтаровтың «Бақытты құлдықтың ақыры» (2005), Ж. Молдағалиевтың «Алғашқы қоңырау» (2005), Қ. Исабайдың «Шоң би» (2005) романдарын айтуға болады. XX ғасырдың екінші жартысында тарихи романдар алдыңғы шепке шықты. Оған дәлел Ілияс Есенберлиннің «Көшпенділер» трилогиясы, Дихан Әбілевтің «Ақын арманы», Әнуар Әлімжановтың «Отырардан келген сый», Мұхтар Мағауиннің «Аласапыран», Әбіш Кекілбаевтың «Елең-алаң», «Үркер», С. Сматаевтың «Елім-ай», Қ. Жұмаділовтің «Соңғыкөш», «Дарабоз»,Ш.Мұртазаның«Қызыл жебе», І. Жақановтың «Ықылас», Н. Әбутәлиевтің «Қайран Нарын», Х. Әдібаевтың «Отырар 
ойраны», Қ. Мұханбетқалиевтің «Бас жұтқан бас», Ә. Сарайдың «Исатай мен Махамбет», Ж. Тұрлыбаевтың «Тамыз таңы», «Райымбек» тарихи романдары. Бұл шығармалардың бәрі де қазақ тарихын байытып қана қоймай, өткеніміздегі ірі тұлғалардың көркем бейнесін жасап, қалың оқырманымыздың тарихи санасын қалыптастырды.

Тәуелсіздік жылдарындағы қазақ әдебиетінде тарихымызды қайтадан жаңа көзқарас тұрғысынан саралау, тарихи оқиғаларға жаңаша баға беру орын алды. Қаламгерлер халқымыздың басынан өткен тарихи бастауларына ден қойды. Осы ретте қаһарманның ішкі әлемнің ұңғылұңғылына бойлау, оның қоршаған ортамен, болмыспен қарым-қатынасын көрсету басты бағдарға айналды.

Қазіргі қазақ тарихи романы қай тұрғыда да толысу, кемелдену, іштей тармақталып, даму үстінде. Жанрлық, тақырыптық, проблемалық салаларымен қатар түр мен стильдік табиғаты, бітімі жағынан даралану, тоғысу сияқты бірбірінен бөлек сипаттағы процестерді де бастан өткеруде.

Қазіргі прозаның, оның ішінде тарихи шығармалардың, тарихи романның кеңістігі шексіз. Өйткені ақиқатты, шындықты боямасыз қалыпта суреттеуге еш кедергі жоқ. Ел тәуелсіздігімен қатар қазақ әдебиеті де соны серпін, жаңа тыныс алды. Теңдіктің туын тік ұстаған тегеурінді, айбынды елдің ұрпақтары тақырыптық мазмұн аясы кең туындыларға қол жеткізді. Сондай шығарманың бірі - «Өмірзая» романы.

Б. Мұқайдың «Өмірзая» романы «Бұл еңбегімді қазақ елінің тәуелсіздігі жолында құрбан болған ерлердің аруағына арнадым. Автор деген арнаумен ашылады. Жазушының өзі меңзегендей, тәуелсіздік жолында құрбан болған ердің бірі - Аяған. Шығармада Аяған Қуатов деген жігіттің куғын мен сүргінге толы аянышты тағдыры суреттелген. Романда тоқырау заманының шындығы, кеңестік дәуірде қоғамда болған көлеңкелі құбылыстар мен сорақы жағдайлар, орыстардың астамшылдық саясатының қазаққа көрсеткен қиянаты көркемдік шешім тапқан. Тоталитарлық тәртіп кезіндегі әділетсіздікпен қарсы күрескен оқымысты жігіт шығарманың өн бойында Ұлы шындық іздеумен өтеді. Ол әділет тілеймін деп кеңестік жүйенің барлық қиянатын, зорлық-зомбылығын көреді. Шығармада сол кездегі шындық реалистік тұрғыда суреттелген [2, 44].

Романда түрлі әлеуметтік оқиғалар легінде сан алуан кедергілерге мойымай, қыл көпір, тас қиядан өтетін, қиын-қыстау шақтарда күресе жүріп өсетін, асқақтай түсетін характер сомдау мақсаты көрсетіледі. Осы тұста бас қаһарманның мінез ерекшелігінен романтикалық бейнелеу тәсіліне тән кейбір ұстанымдарды байқаймыз. Романтикалық әдебиетте кейіпкер өмірден өз жолын, өз орнын таба алмай пұшаймен күй кешеді, тосын шешімге, оқыс әрекетке барады. Өз ісін, мақсатын іске асыру жолында қайғылы қазаға да ұшырайды. Бұл жай Аяғанға да тән.

Аяғанның өмірінде көрген қиянаты мен азабы суреттелген. Тоталитарлық темір жүйенің қатал тәртібіне шыдамаған Аяған қаһармандық қимылы жағынан романтикалық образдарды еске салғанымен, оқиға динамикасы реалистік қуатпен суреттелген. Аяған өзі өмір сүрген қоғамның шындығына көңілі толмай, аласұрып, ортаға қасқайып қарсы тұрады. Онысымен қоймай, тағдыр теперішін көрген кейіпкер өзінен күштілермен ұстасып, идея үшін күреске шығады және сол үшін құрбандыққа да барады. Романтикалық кейіпкерлер сынды сең соққан балықтай күй кешіп, өмірде тығырыққа тіреледі. Автор елінің тәуелсіздігі үшін күрескен қазақ батырлары Кенесары мен Сыздық төремен осы заманда шындық үшін күрескен Аяған, Алдиярлар арасындағы рухани сабақтастықты көрсеткісі келген. Жазушы Аяған мен Алдиярды қазіргі кезеңнің Кенесарысы мен Сыздық төресі деп меңзейді. Шығарма соңында Аяғанға дем беруге Кенесары ханның елесі келеді. Қоғамның бар дертін шындықпен емдегісі келген Аяған: «Сонда шындықты кім айтады? Шындық үшін әйтеуір біреулер құрбандыққа баруы тиіс емес пе?! Болашағы бұлдыр халқының сөзін сөйлеп, туған елінің бақыты, тәуелсіздігі үшін басын оққа байлап беретін марқасқа қайда? Бұл заманның Исатай, Махамбеті, Кенесары, Бекболаты қайда? Олар неге жоқ? Неге?...» [3, 407] - деп толғанады, ерліктері аңызға айналған, елінің еңіреп туған асыл ерлерін жоқтайды.

Жазушы «ақиқат атты арғымаққа мінген, енді Ұлы мақсатына жетемін деп ойлаған, сенген», «адамдардың бәрін дос санап, барлығына адал жүрегінен шыққан адал сөзін» [3, 67] айтқан Аяған образын асқақ бейнелеуге ұмтылады. Аяғанның қарапайым қасиетінен өзгеше қырларын, тұлғасындағы қаһармандық нышанын табуға ұмтылыс кейіпкер образына байланысты шығармада ара-тұра кездесетін кескіндік мінездемелерге романтикалық интонация дарытады.

Аяғанды барша адамзат баласының мәселелері толғандырады. Сондықтан күрескер Аяған 
қоғамдағы зұлымдыққа қарсы шығады. «Аяған үшін шындықтан үлкен ұғым жоқ еді бұл дүниеде. Шындық салтанат құрған жерде қиянат та, қараулық та өмір сүре алмайды деп ойлайтын. Оның түсінігінше Шындық күн сияқты еді» [3, 85].

Шығарма соңындағы романтикалық көрініс - Аяғанның алдына Кенесары мен Сыздық төре аруақтарының келіп, оны күреске жігерлендіруі - романға романтикалық бояу берген. Мұндай романтикалық шешім қаһарманның іс-әрекетіне ірілік беріп, кейіпкер мақсатының маңыздылығын ұштай түскен. Романның құндылықтық бағдарыныңжүйесініңКенесарыменСыздықтөре бейнелері адам бойындағы тұлғалық бастаудың, адамгершілік негізінің символы ретінде және отарлау езгісіне қарсы шығып, еркіндік аңсаған қаһарман күрескерлер бейнесінде көрінеді. Суреткердің көркемдік иерархиясында Кенесары мен Сыздық төре бейнелері, ең алдымен эстетикалық идеал - Тұлғаның идеалы. Б. Мұқай қазақ дүниетанымындағы беделді тұлғаның өз кейіпкерлерінің ең алдымен шығарманың басты қаһарманы Аяғанның іс-әрекеттері мен ой-сезімдерін сабақтас қарайды. «Қор болып тірі болып жүргенше, арпалысып өлген жөн. Елім деп еңіреген талай боздақ көрген кеп бұл» - деп батырлар Аяғанға демеу көрсетеді. Бірақ Аяған түрмеге түскеннен кейін тепкі мен зорлыққа шыдағанымен, қанішерлердің қолынан қаза табады. Аяғанды асып өлтіргеннен кейін «азаматтың күші мәңгілікке кетерде әділеті жоқ дүниені соңғы рет бір тебуге ғана жетті». «Өмірзая» романы «Тіріге опа бермеген жалғанды қап-қара түнек басты, дүниені өлі тыныштық құшағына алды. Аяғанның шыбын жаны торғайға айналып, сонау бір қияндағы бұталарына ұшып кетеді» - деп аяқталады. Өз ортасына сыймаған, соның салдарынан қуғындалған кейіпкердің жаны құсқа айналып, мәңгілікке сапар шегеді. Өзін құрбан ету арқылы өз ортасына, қоғамға қарсылық білдіру романтикалық ыңғайдағы кейіпкерлердің көбіне тән жайт. Шығарманың шешемі - өлім, бірақ трагедия жеке адамнан гөрі қоғам трагедиясына ұласатындай.

«Әдіс» - әдебиет сабақтарындағы мұғалім мен оқушының бірігіп атқаратын оқу-танымдық ic-әрекеті. Сабақ тақырыбына лайық дұрыс таңдалған әдіс арқылы оқушы жаңа білім мазмұнын игереді, жаңа білік-дағдыларға ие болады, қабілеті жетілдіріліп, белгілі бір дүниетанымдық көзқарасы қалптасады [4, 7]. Жоғарыда біз талдаған шығарманы оқытудың сан қилы тәсілдері бар. Бұл ретте біз қазақ әдебиетін оқытудың әдістемесін негізгі басшылыққа аламыз.

Эвристикалық әдіс арқылы көркем әдеби шығармаларды танып-талдау барысында оқушылардың сезімдік көркемдік қабылдауы санада терең иірімдерге бойлай түседі-дағы, олардың интеллектуалдық дамуы қарқындай түседі [5, 22].

«Өмірзая» романын ғалымдар идеялықкөркемдік өрісі кең шығарма деп бағалайды. Бұл романда «Опасыздық-Намыс-Күрес» өрістерінің өзара алмасып отыратын керемет байланысы мен қатынасы гармониялық тізбек пен желіде суреттелген. Баққожа Мұқайдың романын оқырманына жеткіземін деген мақсатын анықтау үшін ұстаз мынадай проблемалық-эвристикалық сұрақтарды алдын ала білімгерге таратып береді:

1. Романда қандай мәселе көтерілді?

А) жеке проблема;

Ә) аймақтық проблема;

Б) ұлттық проблема;

В) жалпыадамзаттық проблема.

2. Аяған үшін осыдан үлкен ұғым жоқ:

А) сатқындық;

Ә) мейірім;

Б) адам;

В) шындық.

3. Романтикалық интонацияны романның қай тұсынан байқаймыз?

Осындай және оған қоса жүргізілетін даярлықтардан соң, эвристикалық әдіс арқылы романның түпкі проблемасын талқылау-талдау жүргізе алады. Мұндай әдістің тиімділігі туралы, әрине, көп айтуға болады. Эвристикалық әдісті қолданған мұғалім алдына қойылған бірнеше міндет тұтастырылып бір мақсаттың көп қыры ретінде шешіліп жатады. Бұл әдіс жекелеген проблемалардың бір арнаға тоғыстырылып, үлкен мәселе ретінде қарастырылып, оқушылардың түрлі сұрақтардың шешімін тауып, оларды тұтастырып, жинақтап отыратын қабілетін қалыптастырады.

«Өмірзая» романын білімгерге жеткізу барысында ізденіс әдісін де қолдануға болады.

Ізденіс әдісін мұғалім білімгердің көркем шығарманы өз бетімен талдауға үйрету мақсатында қолданып, эвристикалық әдісті қолданғанда өзімен бірге жетелеп алып жүретін болса, бұл әдісті қолдануда білімгердің өзінің ізденіс жасауына жол береді.

Романдағы Аяған Қуатовтың іс-әрекеттерін оқи отырып, желтоқсан оқиғасына байланысты тың деректер немесе елеулі әңгімелерді ел 
арасынан жинақтау туралы тапсырма бергені дұрыс. Сонымен қатар, білімгерлер ізденіс үстінде осы оқиғаға қатысқан өзге де ерлердің ерліктерімен танысатын болады. Жазушының басты кейіпкерге қосқан кейбір бояулы тұстарын ізденіс барысында тауып, оған өзінше пікір айтуға мұғалім мүмкіндік беруі керек.

Репродуктивтік немесе көшірмелік әдіс арқылы даяр білім мазмұны жеткізіледі. Негізінде, әдебиет сабақтарында репродуктивтік әдіс үлкен орын алады. Өйткені дайын көркем шығарма мәтінін оку, түрлі талдаулар жасап, тапсырмалар орындау жұмыстары репродуктивтік әдіс арқылы жүзеге асырылады [6, 38].

Б. Мұқайдың романында «Ұлттық намыс» деген киелі ұғымның мән-мағынасын Аяғанның жүрекпен терең ұғынуы, сол сезімді жанжүрегімен сезіне отырып әрекет жасауы аңғартылады. Осыны мұғалім білімгерге романның әрбір тұсына тоқтай отырып түсіндіреді. Яғни, дайын мәтінмен жұмыс жасалады.

Продуктивтік әдістер - әдеби шығармаларды оқып-меңгеруі барысындағы жаңашылдыққа ұмтылысын ынталандыратын, өзгеріске толы заманның ағымында тез бағдар таба алатын, проблеманы көре алатын және оны шешуге қорықпай, шешім жолын іздеп таба алатын, ерекше/оригиналды және шығармашылыққа толы идеяларды табуына ықпалын тигізетін әдіс $[7,29]$. Бұл әдісті кез келген сабақта, кез келген тақырыпта қолдануға болады. Біз талдап отырған шығарманың негізгі мақсаты мен міндеті де осы әдіске келіп тіреледі. Басты кейіпкерді назарға ала отырып, сол кезеңде болған Аяғанның тынымсыз еңбегі мен ақылдылығы, парасаттылығы, мейірімділігі, батылдығы мен батырлығын сөз ете отырып және өзге де кейіпкерлердің тағдыры мен әрекетін сараптай отырып проблемалық жағдаятты білімгердің өзі анықтауына жол ашады.

Бұл романды оқыту барысында эстетикалық тәрбиелеу мәселелері тәсілін қолдана аламыз. Эстетикалық тәрбиелеу - оларды шындық болмысқа деген эстетикалық қарым-қатынасты, көзқарасты мақсатты түрде қалыптастыру жүйесі.

Әдеби шығарма білімгердің мейірімділік пен адамгершілікке, әділдікке деген ұмтылысы, құштарлығын нақты әдеби шығармадағы өмірлікке жақын келетін суреттемелерді меңгерту арқылы оятады. Басты кейіпкердің шындық жолындағы талмай күресі, халқы үшін жанын қиғаны ұрпаққа үлгі болуы керек.

\section{Қорытынды}

«Өмірзая» романын талдау және меңгерту барысында жоғарыда аталған әдеби әдіс- тәсілдерді пайдалансақ болады. Бұл білімгердің романды толықтай меңгеруіне, талдауына, өзіндік ойпікір айтуына жол ашатынымыз анық.

Кез келген ұлт жазушысы - ең алдымен өз ұлтының үні, оның даму тарихындағы ең маңызды деген мәселелерді оқырман қауымға көркемдік кестесімен өрнектей отырып жеткізетін рухани рупоры. Өз халқының ең көкейкесті деген мәселелерін қозғап отыру - қай қаламгердің де абыройлы парызы. Тіпті ол абыройлы ғана емес, туған халқының алдындағы ең қасиетті перзенттік борыштарының бірі. Бұл тарихи-қоғамдық мәселе қазақ тарихи романдарында әр түрлі деңгейде айқынырақ көрініс табуы тиіс. Егер отаншыл рух болмаса, ондай шығарманың әлеуметтік салмағы да азаяр еді. Өйткені қай автор болсын, отаншылдықпатриоттық проблемаларды қиялдан туғызбай, нақты өзі көрген, сезінген, неғұрлым жақсырақ білген жайттардың төңірегінен өрбіткен. Ойдан ойды қозғай отырып, қоғамдық деңгейдегі өзекті мәселелердің көркемдікпен санаға сіңуіне, оқырманды толғантып, тебірентуіне авторлардың жазушылық шеберлігін жұмсауына байланысты екендігі байқалады. Артымыздан ерген ұрпағымыз ұлтымызды, бізді, өзін жоғалтпауы үшін тарихымыздан сыр шертетін сыры мен мұңы жатқан тарихи романдардың салмағы мен сапасын, берер қазынасын ұғынса игі еді.

\section{Әдебиеттер}

Әдебиеттану. Терминдер сөздігі / 3. Ахметов, Т. Шаңбаев. - Алматы: Ана тілі, 1996. - 240 б.

Әйтімов М. Қазіргі романдардағы тарихи шындық пен көркемдік шешім эстетикасы // ҚазҰПУ хабаршысы, 2009. - 4649 б.

Мұқай Б. Өмірзая. - Алматы: Жалын, 1998. - 480 б.

Тәуелсіздік жылдарындағы қазақ әдебиетін оқыту әдістемесі. - Астана, 2013. - 65 б.

Құрман Н. Қазақ тілін оқытудың әдіснамалық негіздері. - Астана, 2005. - 103 б. 
Бітібаева Қ. Әдебиетті оқыту әдістемесі. - Алматы, 1997. - 72 б.

Байтанасова Қ. Қазақ әдебиетін оқыту әдістемесі. - Астана, 2011 - 123 б.

\section{References} Kazakh)

Akhmetov Z., Shanbayev T. (1996). Adebiettany. Terminder sozdigi. [Literature Studies. Glossary.] Almaty, Ana tili, 240 p. (In

Aitimov M. (1996). Kazirgi romandardagy tarihi shyndyk pen korkemdik sheshim estetikasy. [Historical reality and aesthetics of artistic decisions in modern novels.] Almaty, KazUPU khabarshysy, 46-49 p. (In Kazakh)

Baitanasova K. (2011). Kazak adebietin okytu adistemesi. [Methods in teaching Kazakh literature.] Astana, 123 p. (In Kazakh)

Bitibeva K. (1997). Adebietty okyty adistemesi. [Methods in teaching literature.] Almaty, 72 p. (In Kazakh)

Kurman N.. (2005). Kazak tilin okytudyn adisnamalyk negizderi. [Methodological basis of teaching Kazakh language.] Astana, 103 p. (In Kazakh)

Mukai B. (1998) Omirzaya. [Omirzaya.] Almaty: Zhalyn, 480 p. (In Kazakh)

Tauelsizdik zhyldaryndagy kazak adebietin okytu adistemesi. [Teaching Kazakh literature of the independence period] (2013). Astana, 65 p. (In Kazakh) 